\title{
The influence of advertising appeals on viral advertising, brand awareness, and purchase intention: The moderator role of hedonic personality
}

\author{
Wisnu Prajogo ${ }^{1 *}$, Edi Purwanto ${ }^{2}$ \\ ${ }^{1}$ Master of Management Program, STIE YKPN School of Business, Yogyakarta, Indonesia \\ ${ }^{2}$ Master of Management Program, STIE YKPN School of Business, Yogyakarta, Indonesia \\ *Corresponding Author(s) Email: wisnuprajogo@gmail.com
}

\section{ABSTRACT}

Viral advertising has become a trending topic nowadays. This study aims to examine the effect of advertising appeals on viral advertising, brand awareness, and purchase intentions with the hedonic personality playing as a moderating role. The use of hedonic personality itself to predict viral intentions, brand awareness, and purchase intentions have not been widely discussed by other researchers. This study can be classified as explanatory research with purposive sampling and partial least square as sampling techniques and data analysis. This study was designed to focus on individuals who can be classified as social media active users with a minimum age of 18 years old. The result shows that advertising appeals (humor and informative) have a positive and significant impact on viral intention and attitude toward advertisement. Thus, the higher viral intention and the positive attitude toward advertisement will increase the possibility of purchase and the level of brand awareness. While hedonic personality was significantly proved moderates the relationship between viral intentions and brand awareness in this study. The nature of respondents in this study who mainly are at high level of hedonic personality make the moderation role of hedonic personality has no significant impact on the relationship of viral intentions on purchase intentions. Therefore, the viral factor on hedonic consumers did not seem to correlate purchase intentions.

Keywords: Advertising Appeals; Purchase Intentions;

Brand Awareness; Hedonic Personality; Viral

Intentions; Attitude toward Advertising
JEL Code:

M31, M37

DOI:

10.31106/jema.v17i1.5298

Article History:

Received 2020-01-14

Reviewed 2020-01-20

Revised 2020-01-26

Accepted 2020-01-28

Licensed:

CC-BY 


\section{Introduction}

Traditional marketing has lately begun to be abandoned by marketers. Rust \& Oliver (1994) predict that traditional marketing will die and begin to be abandoned. This death is caused by technological advances that produce new media and markets. The internet has a big impact on the world of advertising and business processes (Krishnamurthy \& Singh, 2005). Today's business model is also starting to change and develop along with the development of the internet. Online marketing is a new face for today's business trends. Before the internet came the marketers using television, newspapers, magazines, brochures, and word of mouth in introducing their products to the public (Keller, 2013).

Social media has social power which influences public opinion widely due to the ease of accessing social media by using a cellphone which makes people can easily gain all the intended information. Social media used by marketers to promote and communicate their products and services due to the reason for speediness, widely, and easily accessed (Enyioko \& Okwandu, 2019). Shareef et al. (2019) added that create buzz or word of mouth through social networks considered a robust alternative channel for continuous two-way interactivity nowadays. Many marketers invest their resources to create a best-suited advertising content strategy that can relate to the targeted consumer so that content messages can generate buzz among the social community and goes viral by nature. Moran et al. (2014) added that the message that generates by market or social by nature considered more believable and trustworthy than marketer-initiated messages.

Sharma \& Kaur (2018) who researched global advertising content to explore what factors made the viral content throughout the world, concluded that most of the global advertisements used transformational appeals with positive emotional content in the form of happiness, joy or gladness as the advertisement appeal strategy which then influence consumers intention to purchase and their viral intentions. The success of viral messages determined by entertainment, social needs, and consumer engagement (East et al., 2016). AlRawi (2019) added that several attributes should be concerned by marketers when makes advertisements like information utility or practical value, humorous, and social value.

Based on that researchers want to discuss why an advertisement has become viral and can influence consumers buying behavior. Researchers see a gap that has not been widely discussed by other researchers. The gap is the use of individual preferences like hedonic personality to predict viral intentions, brand awareness, and purchase intentions. Nusair et al. (2017) added that hedonic personality is one of the fundamental factors in predicting the 
willingness to share knowledge and switching cost then affect electronic word of mouth communication. Therefore, the fact that there are limited studies that used individual preferences as a predictor of viral intentions, brand awareness, and purchase intentions need to be examined. This study aims to examine the effect of advertising appeals on viral advertising, brand awareness, and purchase intentions with the hedonic personality playing as a moderating role.

\section{Literature Review}

\section{Advertisement Appeals}

The use of humor advertising appeals in advertising has been widely used by marketers in creating advertisements for a product. A study conducted by Korgaonkar et al. (1997) found that the use of informative, sensuality, and humor advertisements can attract the attention of consumers. Research, in general, shows the attraction that humor has a significant positive influence on consumer attention and recall, and there is potential for improved processing and understanding Weinberger \& Gulas, (1992). Nikolinakou \& King (2018), Petrescu et al. (2016), Wu et al. (2018) added that humorous appeals positively associated with the willingness to share advertising. To sum up, Primanto \& Dharmmesta (2019) concluded that the impact of humorous advertisement not only to entertain the consumers so they would perceive advertisement attitude positively but also influences on word of mouth intention especially since the most successful viral advertisements in the last decade are ad that contains humorous content (Lance \& Guy, 2006).

$\mathrm{H}_{1 \mathrm{a}}$ : Humor advertising has a positive effect on viral intentions.

$\mathrm{H}_{1 \mathrm{~b}}$ : Humor advertising has a positive effect on attitude toward advertising.

Although advertisement that used humor appeals are considered the most effective in influencing consumers, informative advertising also has the advantages of humorous type ad. Consumers can be so involved in humor appeal that they may miss the main message or even brand from the ad. Sung (2016) stressed that informative advertising shows positives attitudes toward advertising on satisfied consumers. Informative advertising will trigger people to create a buzz because they feel there is a benefit in the ad. Petrescu et al. (2016) concluded that not only has a positive effect on attitude towards advertising, informative advertising also influences viral intentions.

$\mathrm{H}_{2 \mathrm{a}}$ : Informative advertising has a positive effect on viral intentions.

$\mathrm{H}_{2 \mathrm{~b}}$ : Informative advertising has a positive effect on attitude toward advertising. 


\section{Viral Intentions}

Just like word of mouth, viral advertising is considered as a more efficient way to lead to competitive advantages. According to Petrescu et al. (2016) the more often people continue advertising it will enable a person to buy the product. This desire to share is called viral intentions. Kim \& Park (2016) defined viral intention as an individual intention to forward an ad. Mahapatra \& Mishra (2017) defined viral as any positive or negative statement made by customers that spread out to large audiences via the Internet. There is a positive influence between viral intentions and purchase intentions (Kudeshia \& Kumar, 2017; Nuseir, 2019). Viral advertising is considered as a good strategy to increase brand awareness. Severi et al. (2014), Vinh et al. (2019) has examined the effect of viral (electronic word of mouth) intentions on brand awareness and the results suggest that viral intentions affect brand awareness.

$\mathrm{H}_{3 \mathrm{a}}$ : Viral intentions has a positive effect on purchase intentions.

$\mathrm{H}_{3 \mathrm{~b}}$ : Viral intentions has a positive effect on brand awareness.

\section{Attitude Toward Advertising}

Attitude toward advertising has been defined as an individual predisposition (feelings and judgment) toward advertisement exposure (Zarouali et al., 2019). While Lee et al. (2016), Sallam \& Algammash (2016) shows the robust relationship between attitude toward advertising and purchase intention. Lancendorfer et al. (2008) indicated that not only influences purchase intentions, attitude toward the advertising also influences brand memorability.

$\mathrm{H}_{4 \mathrm{a}}$ : Attitude toward advertising has a positive effect on purchase intentions.

$\mathrm{H}_{4 \mathrm{~b}}$ : Attitude toward advertising has a positive effect on brand awareness.

\section{Brand Awareness and Purchase Intentions}

While brand awareness is known as individual perceptual and attitudinal brand associations so they can recognize dan recall the brand easily. Purchase intention can be described as the degree that an individual intends to buy a product (Park \& John, 2012). Chung et al. (2016) added that purchase intention is post-behavior after evaluating the overall product attribute and the emotional reaction to take specific actions. The previous study from Chakraborty (2019), Das (2014), Kuang Chi et al. (2009), Lee \& Shin (2010) concluded that there was a significant and positive relationship between brand awareness and purchase 
intention. It means that the more aware consumers toward some brand, the highest the possibility they will purchase the product.

$\mathrm{H}_{5}$ : $\quad$ Brand awareness has a positive effect on purchase intentions.

\section{The Moderator Role of Hedonic Personality}

Individual who have a hedonic personality was more easily influenced by the persuasion of marketers. An individual with hedonic behavior tend to more emotionally in making purchases, they like to make spontaneous purchases. Hedonic behavior is often associated with impulsive buying, the degree to which an individual tendency is convincingly to make an unintended, immediate, and unreflective purchases (Sofi \& Nika, 2017). The study of the moderator role of hedonic personality has been discussed by authors. Chang et al. (2011) Kuikka \& Laukkanen (2012), Overby \& Lee (2006) shows that the moderator effect of hedonic value affects the relationship between retail characteristics, brand equity, trust, value, satisfaction, preferences on positive emotional responses, loyalty brand attitude, behavioral brand loyalty, buying intentions. Kim (2015) stressed that hedonic value is a crucial factor in predicting brand satisfaction and future purchase intention. Sheng \& Teo (2012) Sloot et al. (2005), Wang et al. (2000) added that hedonic value plays an important role to create awareness and association brands in consumers' minds.

$\mathrm{H}_{6 \mathrm{a}}$ : Hedonic personality moderates the relationship between viral intentions and purchase intentions.

$\mathrm{H}_{6 \mathrm{~b}}$ : Hedonic personality moderates the relationship between viral intentions and brand awareness.

\section{Methods}

This study can be classified as explanatory research with purposive sampling as sampling techniques. This study was designed to focus on individuals who can be classified as social media active users with a minimum age of 18 years old. The While validity of the instrument was measured by confirmatory factor analysis. The reliability of the instrument in this study was measured with Cronbach's alpha. Table 2 shows that all item measured in this study is valid and reliable.

Model fit indices are very important measures in managing data because fit indices show the suitability of the model with the data and explain the quality of the model under study. Haribowo (2017) stated that average path coefficient (APC), average R-square (ARS), average variance inflation factor (AVIF) was commonly used to measure the model fitness. 
While the value of APC and ARS that below 0.050 considered as good, the value of AVIF that below 5 considered as fitness. Based on Table 3, it can be concluded that the model of this study meets the criteria for the value of goodness of fit model, therefore the model can be processed into hypotheses testing stages. Hypothesis testing is processed using partial least square by looking at the test results on the estimated value and the P-value.

Table 1. Variable and Item

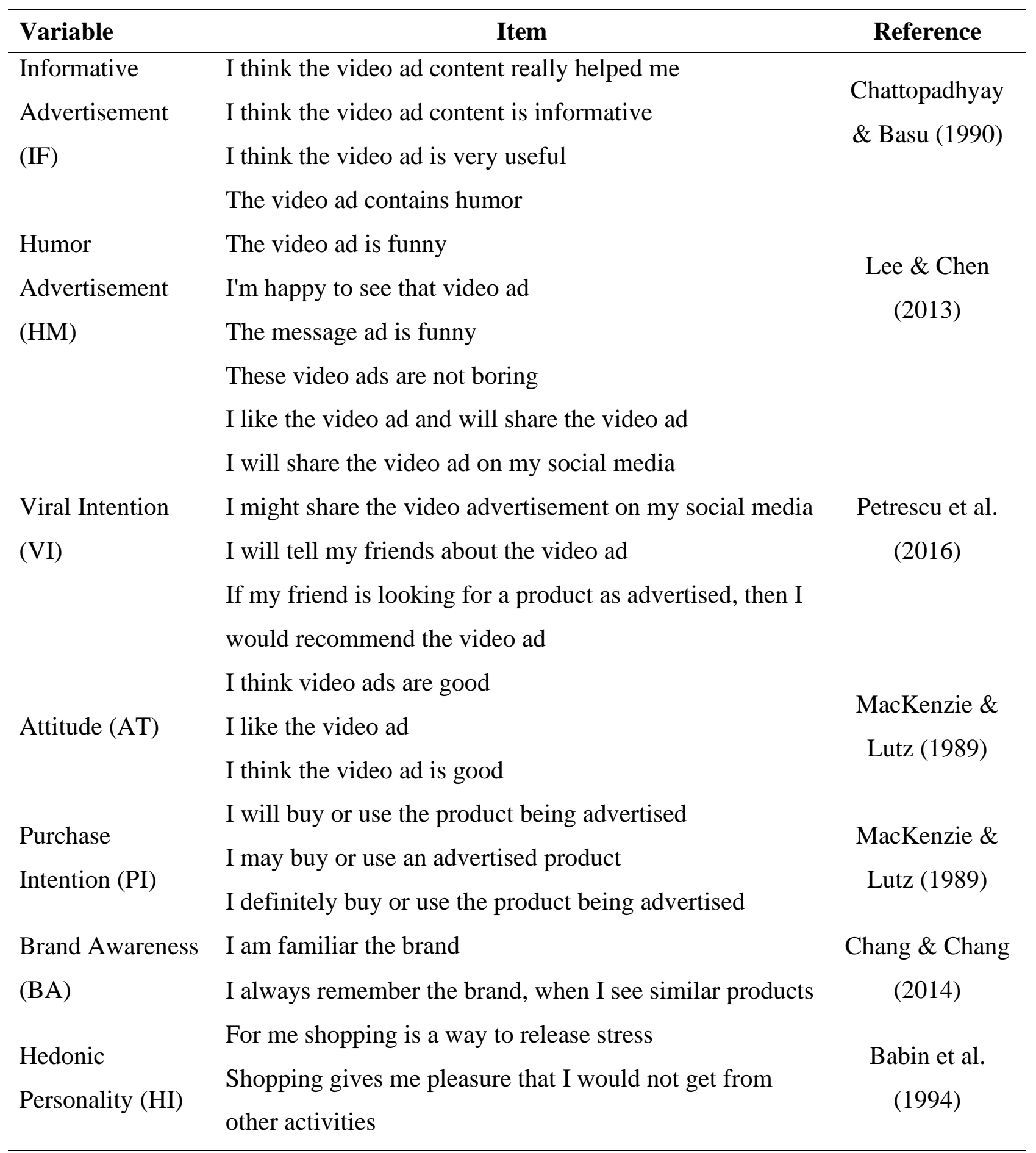


Table 2. Validity and Reliability Test

\begin{tabular}{|c|c|c|c|c|c|}
\hline Variable/Item & $\begin{array}{c}\text { Factor } \\
\text { Loading }\end{array}$ & Criteria & $\begin{array}{c}\text { Cronbach's } \\
\text { alpha }\end{array}$ & Criteria & Decision \\
\hline Informative Ads & & & 0.896 & $>0.600$ & Reliable \\
\hline IF1 & 0.917 & $>0.500$ & & & Valid \\
\hline $\mathrm{IF} 2$ & 0.902 & $>0.500$ & & & Valid \\
\hline IF3 & 0.909 & $>0.500$ & & & Valid \\
\hline Humorous Ads & & & 0.916 & $>0.600$ & Reliable \\
\hline HM1 & 0.713 & $>0.500$ & & & Valid \\
\hline HM2 & 0.768 & $>0.500$ & & & Valid \\
\hline HM3 & 0.737 & $>0.500$ & & & Valid \\
\hline HM4 & 0.758 & $>0.500$ & & & Valid \\
\hline HM5 & 0.768 & $>0.500$ & & & Valid \\
\hline Viral Intentions & & & 0.931 & $>0.600$ & Reliable \\
\hline VI1 & 0.844 & $>0.500$ & & & Valid \\
\hline VI2 & 0.870 & $>0.500$ & & & Valid \\
\hline VI3 & 0.846 & $>0.500$ & & & Valid \\
\hline VI4 & 0.688 & $>0.500$ & & & Valid \\
\hline VI5 & 0.678 & $>0.500$ & & & Valid \\
\hline Attitude towards ad & & & 0.925 & $>0.600$ & Reliable \\
\hline ATT1 & 0.871 & $>0.500$ & & & Valid \\
\hline ATT2 & 0.864 & $>0.500$ & & & Valid \\
\hline ATT3 & 0.882 & $>0.500$ & & & Valid \\
\hline Purchase Intention & & & 0.899 & $>0.600$ & Reliable \\
\hline PI1 & 0.884 & $>0.500$ & & & Valid \\
\hline $\mathrm{PI} 2$ & 0.776 & $>0.500$ & & & Valid \\
\hline $\mathrm{PI} 3$ & 0.845 & $>0.500$ & & & Valid \\
\hline Brand Awareness & & & 0.835 & $>0.600$ & Reliable \\
\hline BA1 & 0.927 & $>0.500$ & & & Valid \\
\hline BA2 & 0.927 & $>0.500$ & & & Valid \\
\hline Hedonic Personality & & & 0.896 & $>0.600$ & Reliable \\
\hline $\mathrm{H} 1$ & 0.783 & $>0.500$ & & & Valid \\
\hline $\mathrm{H} 2$ & 0.792 & $>0.500$ & & & Valid \\
\hline
\end{tabular}


Table 3. Goodness-of-Fit Indexes

\begin{tabular}{lccc}
\hline Index & Value & Criteria & Decision \\
\hline APC & $* * * *$ & $\leq 0.050$ & Ideal \\
ARS & $* * * *$ & $\leq 0.050$ & Ideal \\
AVIF & 1.521 & $<5.000$ & Ideal \\
\hline
\end{tabular}

Note: $* * * *$ means that the probability test value was lower than 0.001

\section{Result and Discussion}

Table 4. Hypotheses Testing

\begin{tabular}{|c|c|c|c|c|}
\hline Hypotheses & Estimation Value & P-Value & Criteria & Decision \\
\hline $\mathrm{H}_{1 \mathrm{a}} \mathrm{HM}$-> VI & 0.360 & $* * * *$ & $\leq 0.050$ & $\mathrm{H}_{1 \mathrm{a}}$ Accepted \\
\hline $\mathrm{H}_{1 \mathrm{~b}} \mathrm{HM}->\mathrm{AT}$ & 0.590 & $* * * *$ & $\leq 0.050$ & $\mathrm{H}_{1 \mathrm{~b}}$ Accepted \\
\hline $\mathrm{H}_{2 \mathrm{a}} \quad \mathrm{IF}->\mathrm{VI}$ & 0.410 & $* * * *$ & $\leq 0.050$ & $\mathrm{H}_{2 \mathrm{a}}$ Accepted \\
\hline $\mathrm{H}_{2 \mathrm{~b}} \quad \mathrm{IF}->\mathrm{AT}$ & 0.320 & $* * * *$ & $\leq 0.050$ & $\mathrm{H}_{2 \mathrm{~b}}$ Accepted \\
\hline $\mathrm{H}_{3 \mathrm{a}} \quad \mathrm{VI}->\mathrm{PI}$ & 0.290 & $* * * *$ & $\leq 0.050$ & $\mathrm{H}_{3 \mathrm{a}}$ Accepted \\
\hline $\mathrm{H}_{3 \mathrm{~b}} \quad \mathrm{VI}->\mathrm{BA}$ & 0.290 & $* * * *$ & $\leq 0.050$ & $\mathrm{H}_{3 \mathrm{~b}}$ Accepted \\
\hline $\mathrm{H}_{4 \mathrm{a}} \quad$ AT $\rightarrow$ PI & 0.250 & $* * * *$ & $\leq 0.050$ & $\mathrm{H}_{4 \mathrm{a}}$ Accepted \\
\hline $\mathrm{H}_{4 \mathrm{~b}} \quad \mathrm{AT} \rightarrow \mathrm{BA}$ & 0.280 & $* * * *$ & $\leq 0.050$ & $\mathrm{H}_{4 \mathrm{~b}}$ Accepted \\
\hline $\mathrm{H}_{5} \quad \mathrm{BA}->\mathrm{PI}$ & 0.380 & $* * * *$ & $\leq 0.050$ & $\mathrm{H}_{5}$ Accepted \\
\hline $\mathrm{H}_{6 \mathrm{a}} \quad \mathrm{VI} * \mathrm{HI}->\mathrm{PI}$ & 0.070 & 0.180 & $\leq 0.050$ & $\mathrm{H}_{6 \mathrm{a}}$ Rejected \\
\hline $\mathrm{H}_{6 \mathrm{~b}} \quad \mathrm{VI} * \mathrm{HI}->\mathrm{BA}$ & -0.200 & $* * * *$ & $\leq 0.050$ & $\mathrm{H}_{6 \mathrm{~b}}$ Accepted \\
\hline
\end{tabular}

Note: $* * * *$ means that the probability test value was lower than 0.010

This study proved all the direct relationship models of the proposed hypotheses. The probability value of that direct relationship was lower than 0.010 which means that $\mathrm{H}_{1 \mathrm{a}}, \mathrm{H}_{1 \mathrm{~b}}$, $\mathrm{H}_{2 \mathrm{a}}, \mathrm{H}_{2 \mathrm{~b}}, \mathrm{H}_{3 \mathrm{a}}, \mathrm{H}_{3 \mathrm{~b}}, \mathrm{H}_{4 \mathrm{a}}, \mathrm{H}_{4 \mathrm{~b}}, \mathrm{H}_{5}$ is accepted. This study support previous studies from Weinberger \& Gulas, (1992). Nikolinakou \& King (2018), Petrescu et al. (2016), Primanto \& Dharmmesta (2019), Wu et al. (2018) that claimed that humorous appeals not only to entertain the consumers so they would perceive advertisement attitude positively but also the willingness to share advertising. Lance \& Guy (2006) added that the most successful viral advertisements in the last decade are ads that contain humorous content.

The result of this study was consistent with previous studies conducted by Petrescu et al. (2016), Sung (2016) which states that informative advertising has a positive effect on attitude toward advertising and viral intentions. Primanto \& Dharmmesta (2019) added that rather 
than humor content, the use of informative appeals appears to be more effective for a highrisk product because consumers tend to be more engaged, involved, and requires extensive thought when evaluating a high-risk product.

This study proved Kudeshia \& Kumar (2017), Nuseir (2019), Severi et al. (2014), Vinh et al. (2019) research that concluded there was a positive and significant relationship between viral intentions and purchase intentions, also viral intentions and brand awareness. Petrescu et al. (2016) added that the more often people continue to share ads, it will enable a person to buy the product. These findings indices that consumer behavior will appear as buying interest when seeing a product with the advert being viral. He also added that viral advertising is considered a good strategy to increase brand awareness. The higher the number of people that shares an advertisement, the advert will become viral, and enhances the familiarity and memorability of the brand. This study also proved Lancendorfer et al. (2008), Lee et al. (2016), Sallam \& Algammash (2016) that concluded there was a positive and significant relationship between attitude toward advertisement and purchase intentions, also an attitude toward advertisement and brand awareness. It means that the more positive consumers' feelings toward ads, the higher their possibility to purchase the brand/product. It also means that the more positive consumers' feelings toward ads, the higher the degree of their memorability and familiarity with the brand/product.

Following the findings in table 4 which shows that the proposed hypotheses of $\mathrm{H}_{5}$ is accepted. It means that the relationship between brand awareness on purchase intentions was positive and significant. This finding is in line with the findings of Chakraborty (2019), Das (2014), Kuang Chi et al. (2009), Lee \& Shin (2010) that concluded that brand awareness can influence consumers to generate interest in buying, consumers will buy a product or brand that they have known before.

Finally, the moderation role of hedonic personality on the relationship between viral intentions and purchase intentions, also the relationship between viral intentions and brand awareness was proved partially. While the probability value of the moderation relationships between viral intentions and brand awareness was lower than 0.010 which means that $\mathrm{H}_{6 \mathrm{~b}}$ is accepted. The probability value of the moderation relationships between viral intentions and purchase intentions was higher than 0.010 (0.180) which means that $\mathrm{H}_{6 \mathrm{a}}$ is rejected. Our respondents can be classified as a high hedonic individual. An individual with a high level of hedonic personality will tend to see the brand first. For them, a brand is about pleasure and joy (Pham et al., 2018). They only buy the brand if it can lift their social class. They are 
purchasing a luxurious and exclusive experience (Kapferer et al., 2014). Therefore, the viral factor on hedonic consumers did not seem to correlate purchase intentions.

\section{Conclusion and Suggestion}

The result shows that advertising appeals (informative and humor) have a positive and significant impact on viral intention and attitude toward advertisement. Thus, the higher viral intention and the positive attitude toward advertisement will increase the possibility of purchase and the level of brand awareness. While hedonic personality was significantly proved moderates the relationship between viral intentions and brand awareness. The nature of respondents in this study who mainly are at the high level of hedonic personality make the moderation role of hedonic personality has no significant impact on the relationship of viral intentions on purchase intentions. Therefore, the viral factor on hedonic consumers did not seem to correlate purchase intentions. Future research should consider another moderator factor such as age, gender, and others that may have an impact on purchase and viral intention.

\section{References}

Al-Rawi, A. (2019). Viral news on social media. Digital Journalism, 7(1), 63-79. https://doi.org/10.1080/21670811.2017.1387062

Babin, B. J., Darden, W. R., \& Griffin, M. (1994). Work and/or fun: Measuring hedonic and utilitarian shopping value. Journal of Consumer Research, 20(4), 644. https://doi.org/10.1086/209376

Chakraborty, U. (2019). The impact of source credible online reviews on purchase intention. Journal of Research in Interactive Marketing, 13(2), 142-161. https://doi.org/10.1108/JRIM-06-2018-0080

Chang, H.-J., Eckman, M., \& Yan, R.-N. (2011). Application of the Stimulus-OrganismResponse model to the retail environment: the role of hedonic motivation in impulse buying behavior. The International Review of Retail, Distribution and Consumer Research, 21(3), 233-249. https://doi.org/10.1080/09593969.2011.578798

Chang, W. Y., \& Chang, I. Y. (2014). The influences of humorous advertising on brand popularity and advertising effects in the tourism industry. Sustainability (Switzerland), 6(12), 9205-9217. https://doi.org/10.3390/su6129205

Chattopadhyay, A., \& Basu, K. (1990). Humor in advertising: The moderating role of prior 
brand evaluation. Journal of Marketing Research, 27(4), 466-476. https://doi.org/10.1177/002224379002700408

Chung, K.-H., Yu, J.-E., Kim, W., \& Shin, J.-I. (2016). The antecedent and consequences of brand image in a low-priced cosmetic brand of South Korea: The moderating effect of gender. International Journal of $U$ - and e- Service, Science and Technology, 9(2), 175184. https://doi.org/10.14257/ijunesst.2016.9.2.18

Das, G. (2014). Linkages of retailer awareness, retailer association, retailer perceived quality and retailer loyalty with purchase intention: A study of Indian food retail brands. Journal of Retailing and Consumer Services, 21(3), 284-292. https://doi.org/10.1016/j.jretconser.2014.02.005

East, R., Uncles, M. D., Romaniuk, J., \& Lomax, W. (2016). Measuring the impact of positive and negative word of mouth: A reappraisal. Australasian Marketing Journal (AMJ), 24(1), 54-58. https://doi.org/10.1016/j.ausmj.2015.12.003

Enyioko, N. C., \& Okwandu, G. A. (2019). Effect of Social Media Marketing on the conversion rate of deposit money banks in Nigeria. JEMA: Jurnal Ilmiah Bidang Akuntansi Dan Manajemen, 16(1), 1. https://doi.org/10.31106/jema.v16i1.2141

Haribowo, I. N. (2017). Pengaruh pengumuman likuidasi bank terhadap minat menarik uang dari bank. MODUS, 29(1), 17-35. https://doi.org/10.24002/modus.v29i1.1037

Kapferer, J.-N., Klippert, C., \& Leproux, L. (2014). Does luxury have a minimum price? An exploratory study into consumers' psychology of luxury prices. Journal of Revenue and Pricing Management, 13(1), 2-11. https://doi.org/10.1057/rpm.2013.34

Keller, K. L. (2013). Building strong brands in a modern marketing communications environment. In D. E. Schultz, C. H. Patti, \& P. J. Kitchen (Eds.), The Evolution of Integrated Marketing Communications: The Customer-Driven Marketplace (pp. 65-82). New York, NY, US: Routledge. https://doi.org/https://doi.org/10.1080/13527260902757530

Kim, W., \& Park, T. (2016). Factors leading to viral intention on exercise posts. In Lecture Notes in Computer Science (including subseries Lecture Notes in Artificial Intelligence and Lecture Notes in Bioinformatics) (pp. 123-129). https://doi.org/10.1007/978-3-31939910-2_12

Kim, Y. (2015). Assessing the effects of perceived value (utilitarian and hedonic) in LCCs 
and FSCs: Evidence from South Korea. Journal of Air Transport Management, 49, 1722. https://doi.org/10.1016/j.jairtraman.2015.07.001

Korgaonkar, P. K., Karson, E. J., \& Akaah, I. (1997). Direct marketing advertising: The assents, the dissents, and the ambivalents. Journal of Advertising Research, 37(5), 4155.

Krishnamurthy, S., \& Singh, N. (2005). The international e-marketing framework (IEMF). International Marketing Review, 22(6), 605-610. https://doi.org/10.1108/02651330510630230

Kuang Chi, H., Ren Yeh, H., \& Ting Yang, Y. (2009). The impact of brand awareness on consumer purchase intention: The mediating effect of perceived quality and brand loyalty. The Journal of International Management Studies, 4(1), 135-144. Retrieved from http://nhuir.nhu.edu.tw/handle/987654321/27159

Kudeshia, C., \& Kumar, A. (2017). Social eWOM: Does it affect the brand attitude and purchase intention of brands? Management Research Review, 40(3), 310-330. https://doi.org/10.1108/MRR-07-2015-0161

Kuikka, A., \& Laukkanen, T. (2012). Brand loyalty and the role of hedonic value. Journal of $\begin{array}{llll}\text { Product } \quad \text { B } & \text { Management, }\end{array}$ https://doi.org/10.1108/10610421211276277

Lance, P., \& Guy, J., G. (2006). From subservient chickens to brawny men: a comparison of viral advertising to television advertising. Journal of Interactive Advertising, 6(2), 2633. https://doi.org/10.1080/15252019.2006.10722116

Lancendorfer, K. M., Atkin, J. L., \& Reece, B. B. (2008). Animals in advertising: Love dogs? Love the ad! Journal of Business Research, 61(5), 384-391. https://doi.org/10.1016/j.jbusres.2006.08.011

Lee, K.-H., \& Shin, D. (2010). Consumers' responses to CSR activities: The linkage between increased awareness and purchase intention. Public Relations Review, 36(2), 193-195. https://doi.org/10.1016/j.pubrev.2009.10.014

Lee, M. J., \& Chen, Y. C. (2013). Underage drinkers' responses to negative-restrictive versus proactive-nonrestrictive slogans in humorous anti-alcohol abuse messages: Are humorous responsible drinking campaign messages effective? Journal of Health Communication, 18(3), 354-368. https://doi.org/10.1080/10810730.2012.727949 
Lee, Y.-G., Byon, K. K., Ammon, R., \& Park, S.-B. R. (2016). Golf product advertising value, attitude toward advertising and brand, and purchase intention. Social Behavior and Personality: An International Journal, 44(5), 785-800. https://doi.org/10.2224/sbp.2016.44.5.785

MacKenzie, S. B., \& Lutz, R. J. (1989). An empirical examination of the structural antecedents of attitude toward the ad in an advertising pretesting context. Journal of Marketing, 53(2), 48-65. https://doi.org/10.1177/002224298905300204

Mahapatra, S., \& Mishra, A. (2017). Acceptance and forwarding of electronic word of mouth. Marketing Intelligence \& Planning, 35(5), 594-610. https://doi.org/10.1108/MIP-012017-0007

Moran, G., Muzellec, L., \& Nolan, E. (2014). Consumer moments of truth in the digital context. Journal of Advertising Research, 54(2), 200-204. https://doi.org/10.2501/JAR54-2-200-204

Nikolinakou, A., \& King, K. W. (2018). Viral Video Ads: Examining Motivation Triggers to Sharing. Journal of Current Issues \& Research in Advertising, 39(2), 120-139. https://doi.org/10.1080/10641734.2018.1428247

Nusair, K., Hua, N., Ozturk, A., \& Butt, I. (2017). A theoretical framework of electronic word-of-mouth against the backdrop of social networking websites. Journal of Travel \& Tourism Marketing, 34(5), 653-665. https://doi.org/10.1080/10548408.2016.1218404

Nuseir, M. T. (2019). The impact of electronic word of mouth (e-WOM) on the online purchase intention of consumers in the Islamic countries - a case of (UAE). Journal of Islamic Marketing, 10(3), 759-767. https://doi.org/10.1108/JIMA-03-2018-0059

Overby, J. W., \& Lee, E.-J. (2006). The effects of utilitarian and hedonic online shopping value on consumer preference and intentions. Journal of Business Research, 59(10-11), 1160-1166. https://doi.org/10.1016/j.jbusres.2006.03.008

Park, J. K., \& John, D. R. (2012). Capitalizing on brand personalities in advertising: The influence of implicit self-theories on ad appeal effectiveness. Journal of Consumer Psychology, 22(3), 424-432. https://doi.org/10.1016/j.jcps.2011.05.004

Petrescu, M., Korgaonkar, P. K., Mangleburg, T. F., \& Root, A. R. (2016). Ad appeals in the context of viral advertising. In K. Plangger (Ed.), Thriving in a New World Economy (pp. 95-95). Springer, Cham. https://doi.org/10.1007/978-3-319-24148-7_29 
Pham, M., Valette-Florence, P., \& Vigneron, F. (2018). Luxury brand desirability and fashion equity: The joint moderating effect on consumers' commitment toward luxury brands. Psychology \& Marketing, 35(12), 902-912. https://doi.org/10.1002/mar.21143

Primanto, A. B., \& Dharmmesta, B. S. (2019). What happens after they laugh: How humorous advertisements have an effect on consumers' attitudes, word of mouth intentions, and purchase intentions, with the need for humor playing a moderating role. Journal of Indonesian Economy and Business, 34(2), 117. https://doi.org/10.22146/jieb.23036

Rust, R. T., \& Oliver, R. W. (1994). The death of advertising. Journal of Advertising, 23(4), 71-77. https://doi.org/10.1080/00913367.1943.10673460

Sallam, M. A., \& Algammash, F. A. (2016). The effect of attitude toward advertisement on attitude toward brand and purchase intention. International Journal of Economics, Commerce and Management, 4(2), 509-520.

Severi, E., Choon Ling, K., \& Nasermoadeli, A. (2014). The impacts of electronic word of mouth on brand equity in the context of social media. International Journal of Business and Management, 9(8), 84-96. https://doi.org/10.5539/ijbm.v9n8p84

Shareef, M. A., Mukerji, B., Dwivedi, Y. K., Rana, N. P., \& Islam, R. (2019). Social media marketing: Comparative effect of advertisement sources. Journal of Retailing and Consumer Services, 46, 58-69. https://doi.org/10.1016/j.jretconser.2017.11.001

Sharma, R. R., \& Kaur, B. (2018). Modeling the elements and effects of global viral advertising content: A cross-cultural framework. Vision: The Journal of Business Perspective, 22(1), 1-10. https://doi.org/10.1177/0972262917750225

Sheng, M. L., \& Teo, T. S. H. (2012). Product attributes and brand equity in the mobile domain: The mediating role of customer experience. International Journal of Information Management, $\quad 32(2), \quad$ 139-146. https://doi.org/10.1016/j.ijinfomgt.2011.11.017

Sloot, L. M., Verhoef, P. C., \& Franses, P. H. (2005). The impact of brand equity and the hedonic level of products on consumer stock-out reactions. Journal of Retailing, 81(1), 15-34. https://doi.org/10.1016/j.jretai.2005.01.001

Sofi, S. A., \& Nika, F. A. (2017). Role of intrinsic factors in impulsive buying decision: An empirical study of young consumers. Arab Economic and Business Journal, 12(1), 29- 
43. https://doi.org/10.1016/j.aebj.2016.12.002

Sung, J. (2016). The effectiveness of advertisement after consumer dissatisfaction. International Journal of IT Business Strategy Management, 2(1), 47-52. https://doi.org/10.21742/ijibsm.2016.2.08

Vinh, T. T., Phuong, T. T. K., Nga, V. T. Q., \& Nguyen, N. P. (2019). The effect of social media communication on brand equity through Facebook: evidence from CGV Cinemas, Vietnam. International Journal of Electronic Customer Relationship Management, $12(2), 143-166$.

Wang, C.-L., Chen, Z.-X., Chan, A. K. K., \& Zheng, Z.-C. (2000). The influence of hedonic values on consumer behaviors. Journal of Global Marketing, 14(1-2), 169-186. https://doi.org/10.1300/J042v14n01_09

Weinberger, M. G., \& Gulas, C. S. (1992). The impact of humor in advertising: a review. Journal of Advertising, 21(4), 35-59. https://doi.org/10.1080/00913367.1992.10673384

Wu, C., Sundiman, D., Kao, S.-C., \& Chen, C.-H. (2018). Emotion induction in click intention of picture advertisement: a field examination. Journal of Internet Commerce, 17(4), 356-382. https://doi.org/10.1080/15332861.2018.1463803

Zarouali, B., Poels, K., Walrave, M., \& Ponnet, K. (2019). The impact of regulatory focus on adolescents' evaluation of targeted advertising on social networking sites. International Journal of Advertising, $38(2)$, $316-335$. https://doi.org/10.1080/02650487.2017.1419416 
The influence of advertising appeals on viral advertising, brand awareness, and purchase intention:

The moderator role of hedonic personality by Wisnu Prajogo, Edi Purwanto

\section{Appendix 1. PLS Result}

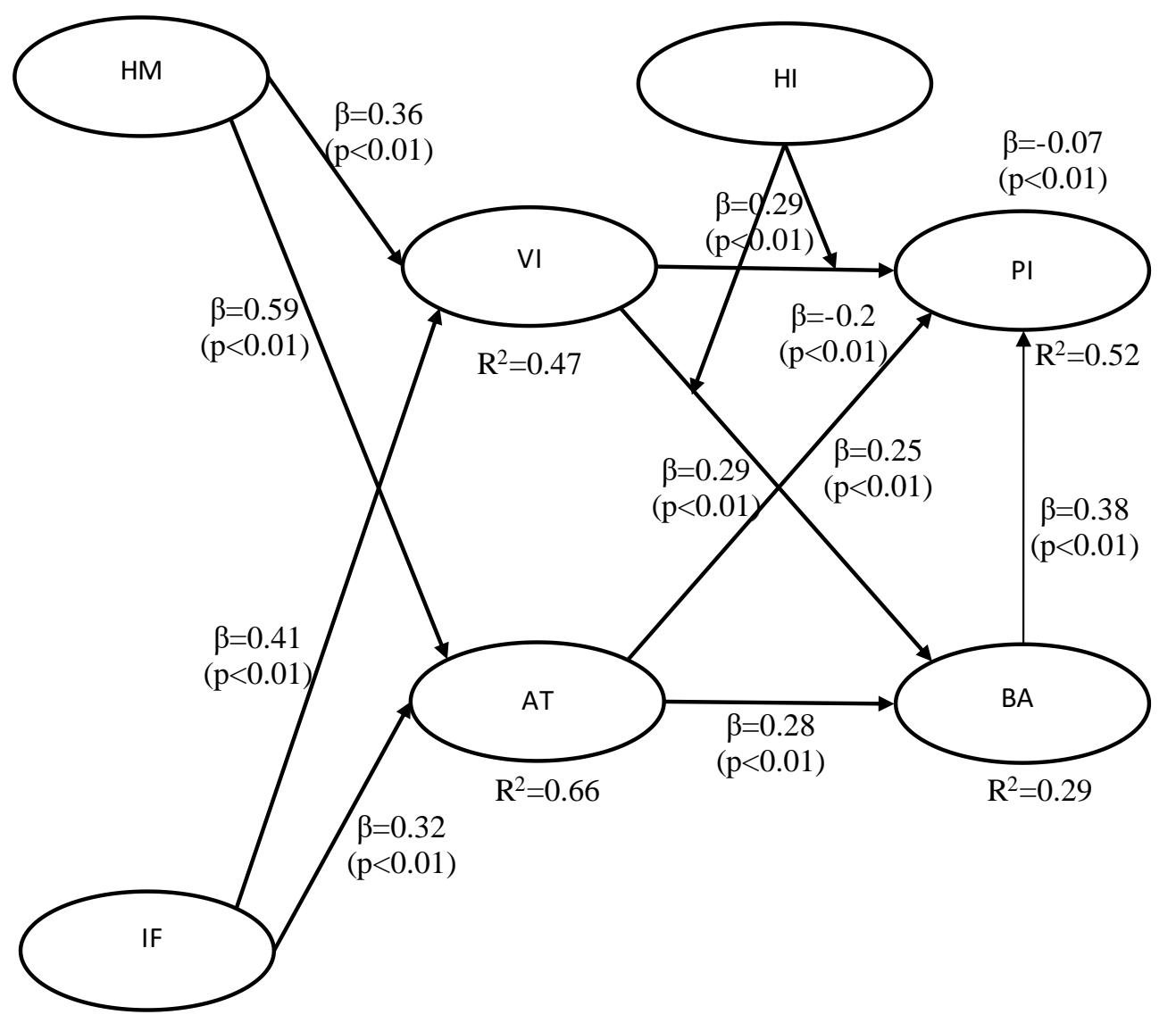

